\title{
Climate-Induced Gradients of Populus sp. Forest Biomass on the Territory of Eurasia
}

\author{
Vladimir Usoltsev ${ }^{1,2^{*}}$, Omid Shobairi ${ }^{3}$, Viktor Chasovskikh ${ }^{1}$ \\ 1 Ural State Forest Engineering University, Sibirskiy Trakt, 37, Yekaterinburg, 620100 Russia \\ 2 Botanical Garden of the Ural Branch of RAS, 8 Marta Str., 202a, Yekaterinburg, 620144 Russia \\ 3 Nanjing Forestry University, Nanjing Shi, Jiangsu Sheng, 210037 China \\ * Corresponding author's e-mail: Usoltsev50@mail.ru
}

\begin{abstract}
On the basis of the compiled database in a number of 413 sample plots with determinations of forest biomass of the genus Populus sp. on the territory of Eurasia from France to southern China and Japan statistically significant transcontinental decreasing of stem, aboveground and total biomass as in the direction from northern temperate to subequatorial zonal belt and in the direction from the Atlantic and Pacific coasts to the continentality pole in Siberia is established. Unlike wood story, understory biomass in these directions has not decreased, and increasing. The root: shoot ratio increases in the range between northern temperate and subequatorial zonal belts from 15 to $32 \%$ and within the southern temperate zone it monotonically increases from $5 \%$ on the oceanic coasts to $40 \%$ near continentality pole. The ratio of understory to wood story biomass increases from 0.3 to $1.6 \%$ ranging from northern temperate to subequatorial zonal belt, and within the south temperate zone it monotonically increases from zero values near Atlantic and Pacific coasts, approaching the level of $40 \%$ near the continentality pole. The results can be useful in the management of biosphere functions of forests, what is important when implementing activities on climate stabilization, as well as in the validation of the results of the simulations for assessing the carbon-depositing forest capacity.
\end{abstract}

Keywords: genus Populus sp., biomass, phytogeography, woody story, understory, natural zones, climate continentality index.

\section{INTRODUCTION}

In connection with the problem of global climate change, forest biomass is seen as their main characteristic determining the course of processes in forest ecosystems and used for environmental monitoring, sustainable forest management, modeling forest productivity taking into account global changes, study the structure and biodiversity of forest cover as well as assessment of carbon-depositing capacity of forests. Biomass of plant cover is determined by many factors, of which the most important is the climatic one associated with the intensity of solar radiation and climate continentality (Grigoriev, Budyko, 1956; Nazimova, 1995). This paper is devoted to re- vealing of transcontinental climate-caused trends in the biomass structure of short rotation woody crop Populus sp.

When using the compiled by the authors the forest biomass database in a number of 8 thousand sample plots (Usoltsev, 2013), the data of 413 plots with biomass determination are extracted for the analysis of geographic patterns of distribution of Populus forest biomass on the territory of Eurasia. Biomass data are presented with different components (stems, branches, foliage, roots and understory including grass cover, bushes, shrubs and ingrowth). Allocation of plots with determinations of Populus forest biomass is shown on the map of Eurasia in Figure 1 and dividing to wood species and countries - in the Table 1 . 
Table 1. Distribution of plots with determinations of Populus biomass ( $\mathrm{t} / \mathrm{ha}$ ) by species and countries

\begin{tabular}{|l|l|l|c|}
\hline \multicolumn{1}{|c|}{ Species } & \multicolumn{1}{|c|}{ Botanical title } & \multicolumn{1}{c|}{ Plot quantity } \\
\hline Quaking aspen & Populus tremula L. & $\begin{array}{l}\text { Russia, Ukraine, Kazakhstan, } \\
\text { Estonia, Belarus }\end{array}$ & 188 \\
\hline David's aspen & P. davidiana Dode & China, Japan & 129 \\
\hline Californian poplar & P. trichocarpa Torr. \& A.Gray ex Hook. & $\begin{array}{l}\text { France, Austria, Belgium, } \\
\text { Netherlands }\end{array}$ & 37 \\
\hline Poplar larrity & P. laurifolia Ledeb. & Russia & 12 \\
\hline White poplar & P. alba Ledeb. & Russia, Kazakhstan & 10 \\
\hline Poplar «Robusta» & Populus $\times$ euroamericana & Ukraine & 10 \\
\hline Asiatic poplar & P. euphratica Olivier & China & 9 \\
\hline Hybrid & Populus hybrid & Japan & 6 \\
\hline Poplar berry-bearing & $\begin{array}{l}\text { P. deltoids W.Bartram ex Humphry Mar- } \\
\text { shall }\end{array}$ & China & 2 \\
\hline Black poplar & P. nigra L. & Russia & 1 \\
\hline Bahala poplar & Populus $\times$ bachelieri Solemacher & Bulgaria & 1 \\
\hline Ploomy poplar & P. pruinosa Schrenk & Tajikistan & 413 \\
\hline \multicolumn{1}{|c|}{ Total } & & 6 \\
\hline
\end{tabular}

\section{MATERIAL AND METHODS}

As plots for estimating biomass of forest stands are usually established in typical 'background' habitats, that are representative in relation to this type of plant communities, one can make on their basis a preliminary geographical analysis of biomass gradients of pine forests. For analytical description of geographic distribution patterns of biomass productivity of forest cover, one must choose the geographical characteristics of the territory of Eurasia, that can be expressed by the quantity and measure. Global primary production dependencies of forest cover from evapotranspiration (Rosenzweig, 1968), as well as on the amount of precipitation and the average annual temperature (Lieth, 1974) are known, but they are fulfilled on the basis of single regressions, excluding conjugate estimation of determining factors.
The same wood species cannot be grown throughout Eurasia, and habitats of different species are associated with specific eco-regions (e.g., Populus nigra in France and P. Davidiana in Japan). This phenomenon in plant communities chorology (Tolmachev, 1962) is known as the substitution of species: replacing or vicarious species of plants occur in the cases of geologically long-time separation of once continuous area. If we want to analyze the geography of biomass in the broadest geographic ranges, we encounter inevitable with the phenomenon of substitution of species. Therefore, geographical analysis is made at the level of the vicarious species within the genus Populus, and the distribution of plots with the determinations of biomass at Eurasian map is shown in Figure 1.

The first attempt to build a zonal profile of biomass productivity of forest vegetation of the

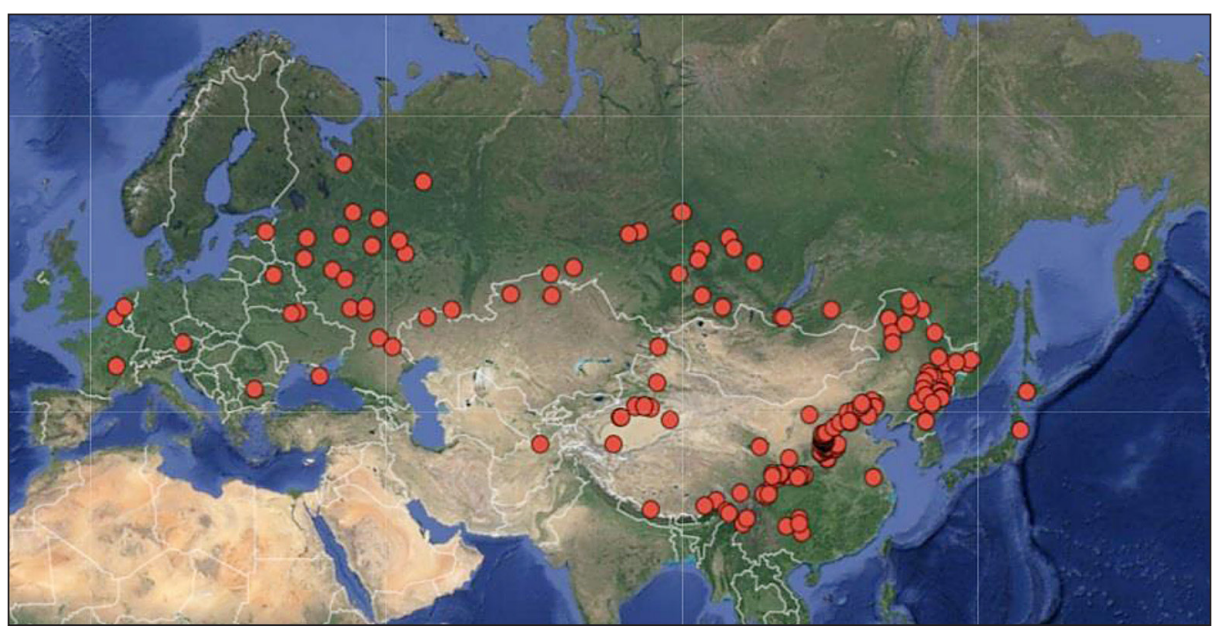

Fig. 1. Allocation of sample plots with biomass (t/ha) determinations in a number of 413 Populus forest stands on the territory of Eurasia 
European part of Russia have taken E.M. Lavrenko et al., 1955. V.L. Komarov (1921) was developed the doctrine of meridional zonation of vegetation, that complements the latitudinal zonation and should be taken into account in the allocation of biogeographical regions. He distinguishes between the two types of major continental floras: near oceanic, elongated along the coasts, and continental, developing in the distance from the first. The intersecting with known seven latitude zones, they give on the spaces of Old and New world 42 floral district.

Actual 413 Populus biomass sample plot allocations (see Figure 1) we related with 4 regional zones (northern temperate, southern temperate, subtropical and subequatorial), coded by serial numbers 2, 3, 4 and 5 (see Figure 2), as well as according to continentality index on the territory of Eurasia by S.P. Khromov (Figure 3) by drawing on the maps the coordinates of each plot.

Basic principles of modelling and the results obtained by means of regression analysis should have ecologic-geographical interpretation. Biological productivity of forests is depending on climatic factors, but only as a first approximation, since there are ontogenetic, cenotic, edaphical, and other levels of its variability. Therefore, we include in the regression equations the independent variables explaining the variability of the dependent variable, expressing not only with climatic parameters but also with forest age, tree density and stem volume. Then the technique of multivariate regression analysis according to two blocks of recursive equations is used: block of two massforming indices $N$ and $M$ and block of biomass $P i$ (arrows show the sequence of calculations)

$$
\begin{gathered}
N=\mathrm{f}(A, Z o n, I C) \rightarrow M=\mathrm{f}(A, N, \text { Zon, } \\
I C) \rightarrow P i=\mathrm{f}(A, N, M, Z o n, I C)
\end{gathered}
$$

where: $N$ - tree number, thousands of individuals per ha;

$A$ - forest age, yrs;

$M$ - stem volume, $\mathrm{m}^{3}$ per ha;

$P_{i}$ - dry biomass of stems above bark, branches, needles, roots, aboveground, total tree story and understory (correspondingly $P_{S}, P_{B}, P_{F}, P_{R}, P_{A}, P_{T}$ and $\left.P_{U}\right), \mathrm{t}$ per ha;

Zon - zonal belt number: 2, 3, 4 and 5 , correspondingly northern temperate, southern temperate, subtropical and subequatorial;

IC - climate continentality index by S.P. Khromov, \%.

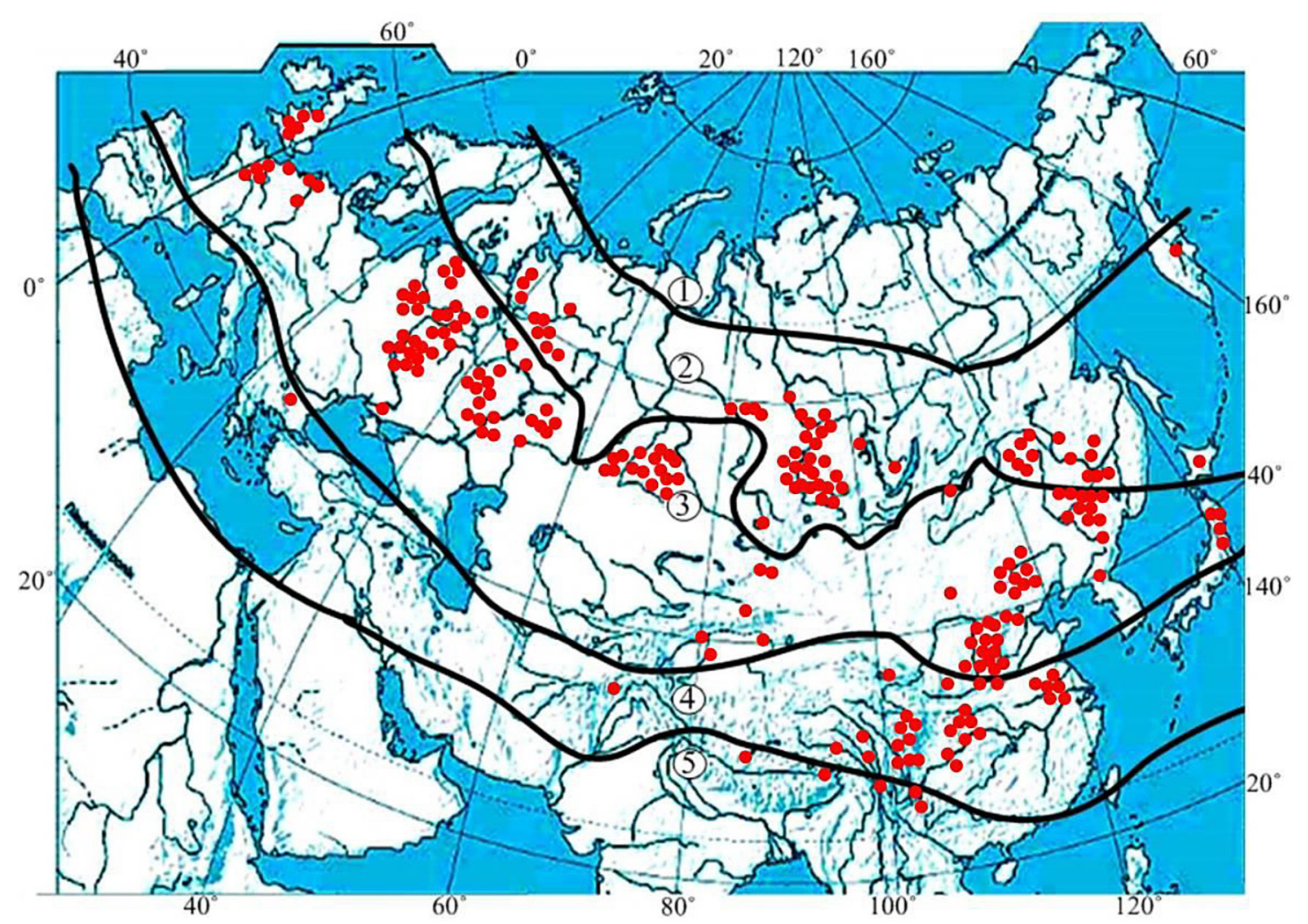

Figure 2. Allocation of sample plots having Populus forest biomass ( $\mathrm{t} / \mathrm{ha}$ ) measurements according to zonal belts:: 1 - subarctic, 2 - northern temperate, 3 - southern temperate, 4 - subtropical, 5 - subequatorial (Alisov, Poltaraus, 1974; Bazilevich, Rodin, 1967) 


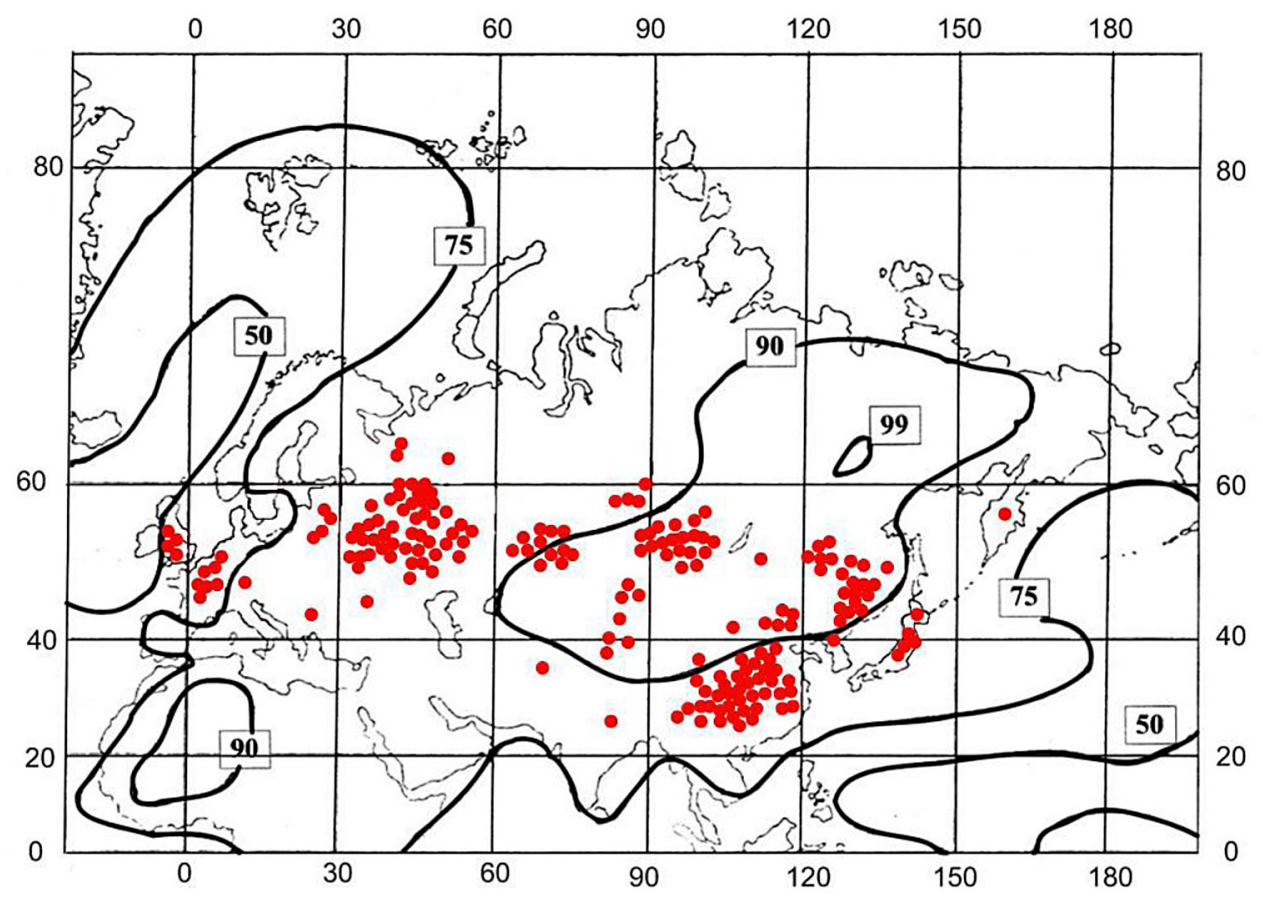

Figure 3. Isoline map of climate continentality of Eurasia (Khromov, 1957) with the situation of plots on which biomass of Populus forests ( $\mathrm{t} / \mathrm{ha}$ ) is estimated

In indices of $P_{A}$ and $P_{T}$ the wood biomass without understory is only involved. For the last component the equation (1) is calculated separately.

\section{RESULTS AND DISCUSSION}

Results of calculation of equations (1) are listed in the Table 2. Only the variables that are significant at the level of probability of $\mathrm{P}_{95}$ and above are showed in the equations. The equations are tabulated in the sequence illustrated by arrows, using forest age, zonal number and continentality index values in the range from 20 up to 100 years old (not shown here). From the calculated age-related table the values of the desired indices for age 50 years are taken and they are presented as graphs of their relations to the zoning of the territory and its climate continental index (Figures 4 and 5).

According to the results obtained, biomass of foliage and roots is monotonically increasing in the direction from 2 nd to 5 th zonal belt (Figure $4 a, d$ ), the biomass of branches is changed in the form of the bell-shaped curve with a maximum in the 4 th zonal belt (Figure $4 b$ ) and aggregate component indices -aboveground and total biomass are decreasing from the 2 nd to the 5 th belt (Figure $4 e, f$ ). With a fixed zonal belt (in this case the zonal belt 3 ) the biomass of stems, above ground and total wood story are monotonically decreasing in the direction from the Atlantic and Pacific coasts to continentality pole in Yakutia (Figure 5).

Change of calculated estimates of understory biomass according to transcontinental gradients is opposite in comparison with the change of aboveground and total biomass of forest stands, i.e. increase both in direction from North to South (from 2-th to 5th zonal belt), and in direction from the Atlantic and Pacific coasts to continentality pole in Yakutia (Figure 6). $P_{R} / P_{A}$ and $P_{U} / P_{T}$ ratios change on the same path, i.e. increase both in direction from 2-nd to 5 th zonal belt and according to continentality increasing (Figures 7 and 8).

\section{CONCLUSIONS}

On the basis of the compiled database in a number of 413 sample plots with determinations of forest biomass of the genus Populus sp. on the territory of Eurasia from France to southern China and Japan statistically significant transcontinental decreasing of stem, aboveground and total biomass as in the direction from northern temperate to subequatorial zonal belt and in the direction from the Atlantic and Pacific coasts to the continentality pole in Siberia is established. Unlike wood story, understory biomass in these directions has not decreased, and increasing. 
Table 2. The characteristic of equations (1) to Populus forests of Eurasia

\begin{tabular}{|c|c|c|c|c|c|c|}
\hline \multirow{2}{*}{$\begin{array}{c}\text { Dependent } \\
\text { variables }\end{array}$} & \multicolumn{6}{|c|}{ Coefficients and independent variables } \\
\hline & $a_{0}$ & $a_{1}(\ln A)$ & $a_{2}(\ln A)^{2}$ & $a_{3}(\ln N)$ & $a_{4}(\ln N)^{2}$ & $a_{5}(\ln M)$ \\
\hline $\ln (N)$ & -9.7129 & -1.3162 & - & - & - & - \\
\hline $\ln (M)$ & 20.7867 & 1.4888 & -0.1525 & -0.1447 & - & - \\
\hline $\ln \left(P_{S}\right)$ & -0.3102 & 0.7072 & -0.0759 & 0.0656 & - & 0.8904 \\
\hline $\ln \left(P_{B}\right)$ & -10.2663 & 0.0818 & - & -0.0809 & - & 0.6149 \\
\hline $\ln \left(P_{F}\right)$ & -9.0230 & -1.6727 & 0.2464 & 0.2037 & -0.0584 & 1.0169 \\
\hline $\ln \left(P_{R}\right)$ & -7.4416 & 0.1362 & - & 0.2147 & -0.0672 & 2.1117 \\
\hline $\ln \left(P_{A}\right)$ & -1.4823 & 0.1480 & - & 0.0733 & -0.0235 & 0.8222 \\
\hline $\ln \left(P_{T}\right)$ & -2.5039 & 0.7009 & -0.0759 & 0.1372 & -0.0480 & 0.7408 \\
\hline $\ln \left(P_{U}\right)$ & -27.8283 & -2.5891 & 0.3591 & 0.0724 & -0.1466 & 0.2040 \\
\hline $\begin{array}{c}\text { Dependent } \\
\text { variables }\end{array}$ & $\begin{array}{c}a_{6} \\
(\ln M)^{2}\end{array}$ & $\begin{array}{c}a_{7} \\
\ln (\text { Zon })\end{array}$ & $\begin{array}{c}a_{8} \\
(\ln Z o n)^{2} \\
\end{array}$ & $\begin{array}{c}a_{9} \\
\ln (I C)\end{array}$ & $\mathrm{R}^{2}$ & SE \\
\hline $\ln (N)$ & - & -0.3785 & - & 3.4152 & 0.671 & 0.60 \\
\hline $\ln (M)$ & - & -0.9917 & - & -4.0415 & 0.410 & 0.56 \\
\hline $\ln \left(P_{S}\right)$ & - & 0.4460 & -0.1743 & -0.3913 & 0.964 & 0.16 \\
\hline $\ln \left(P_{B}\right)$ & - & 1.6649 & -0.4247 & 1.8440 & 0.731 & 0.39 \\
\hline $\ln \left(P_{F}\right)$ & -0.0656 & 0.7527 & - & 1.9643 & 0.552 & 0.38 \\
\hline $\ln \left(P_{R}\right)$ & -0.1535 & 0.5646 & - & 0.6824 & 0.721 & 0.31 \\
\hline $\ln \left(P_{A}\right)$ & - & 0.2234 & - & 0.2387 & 0.954 & 0.17 \\
\hline $\ln \left(P_{T}\right)$ & - & 0.9806 & -0.3071 & 0.3089 & 0.908 & 0.17 \\
\hline $\ln \left(P_{u}\right)$ & - & 1.4548 & - & 6.9682 & 0.557 & 0.40 \\
\hline
\end{tabular}

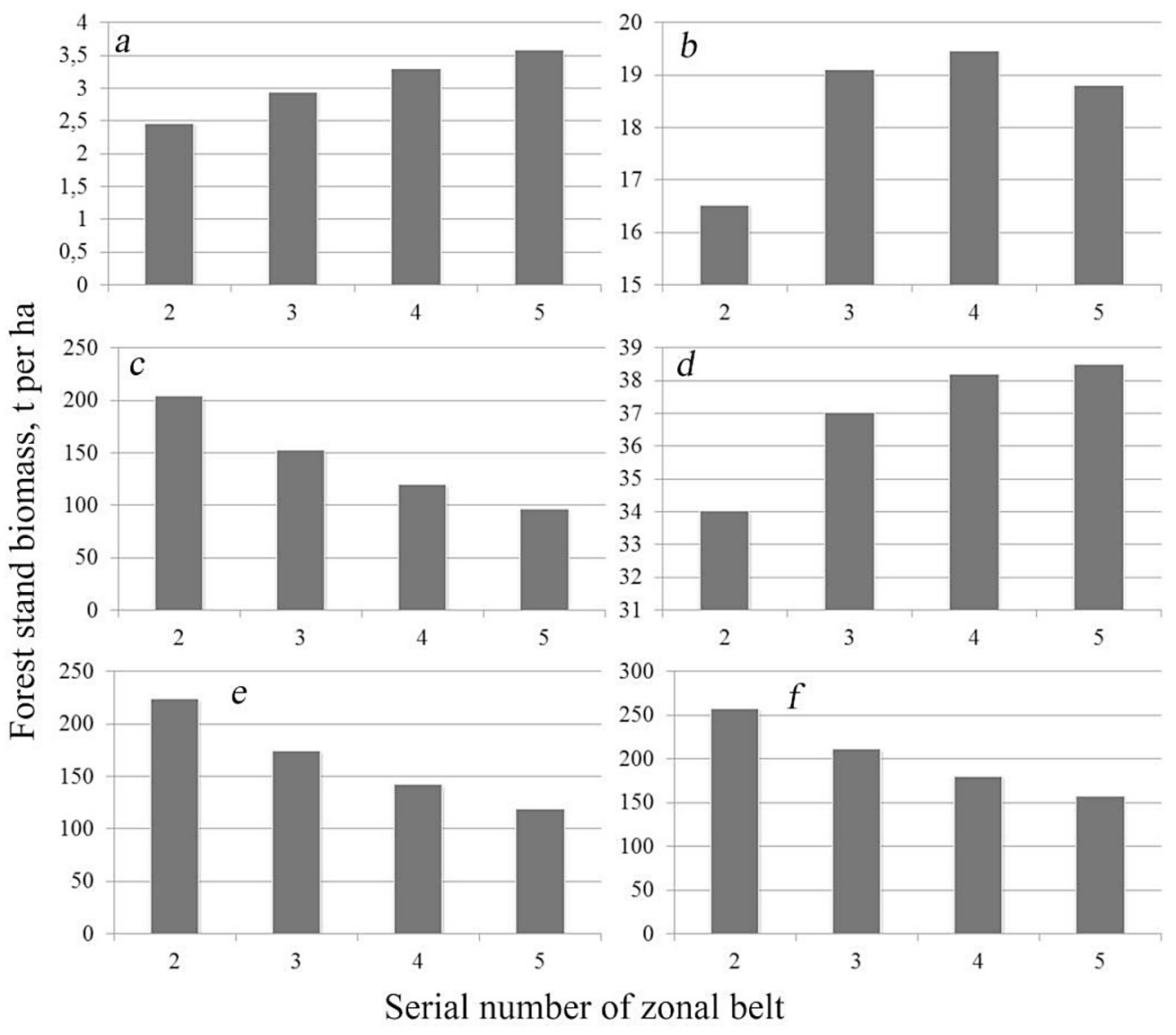

Figure 4. Dependence of the estimated biomass of foliage $(a)$, branches $(b)$, stems $(c)$, roots $(d)$, aboveground $(e)$ and total tree story $(f)$ at the age of 50 years from the zonal affiliation of Populus forests in continentality index equal равном $75 \%$. 


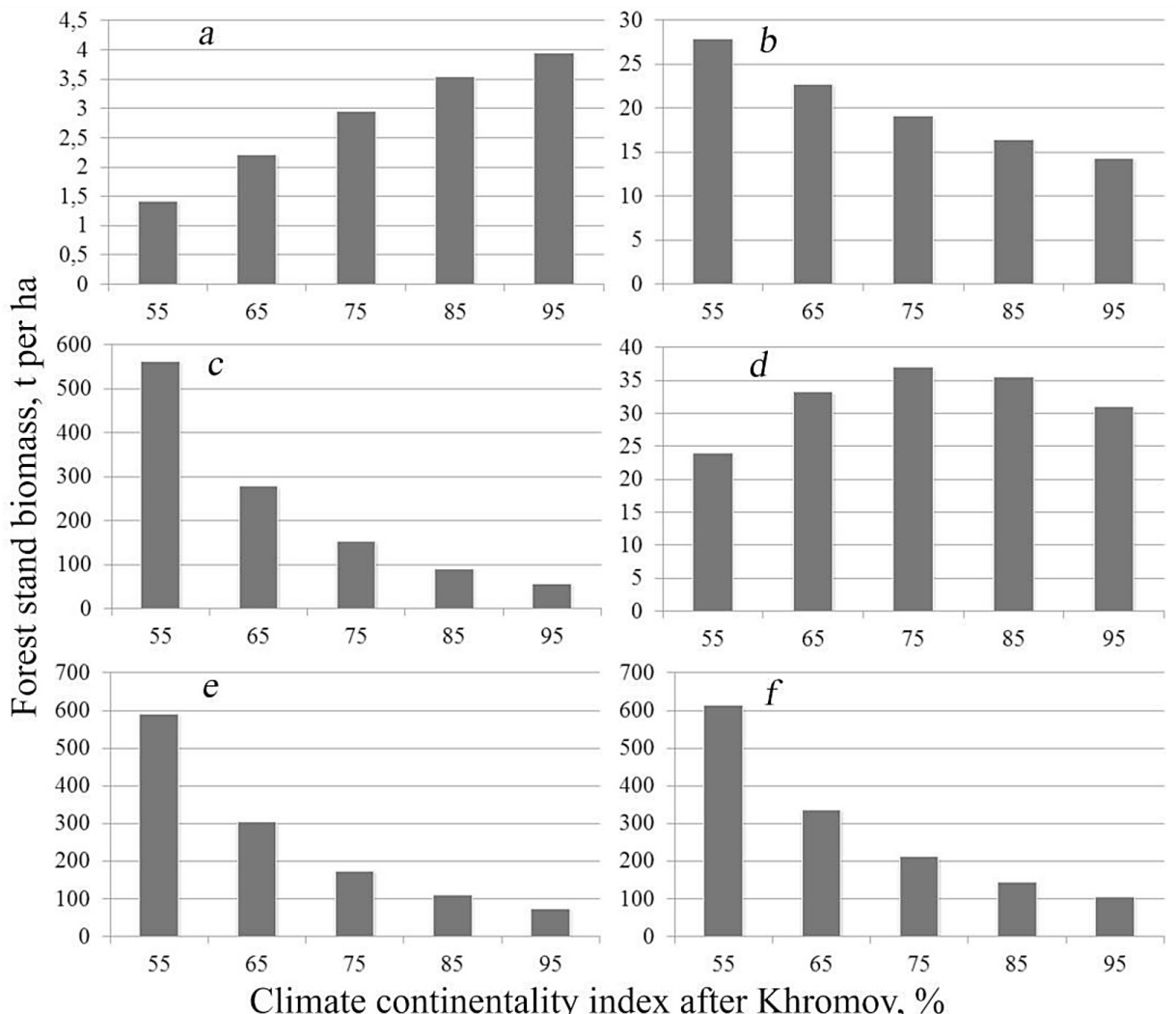

Figure 5. Dependence of the estimated biomass of foliage (a), branches $(b)$, stems $(c)$, roots $(d)$, aboveground $(e)$ and total tree story $(f)$ of Populus forests at the age of 50 years in the southern temperate climatic zone upon the continentality index after S.P. Khromov
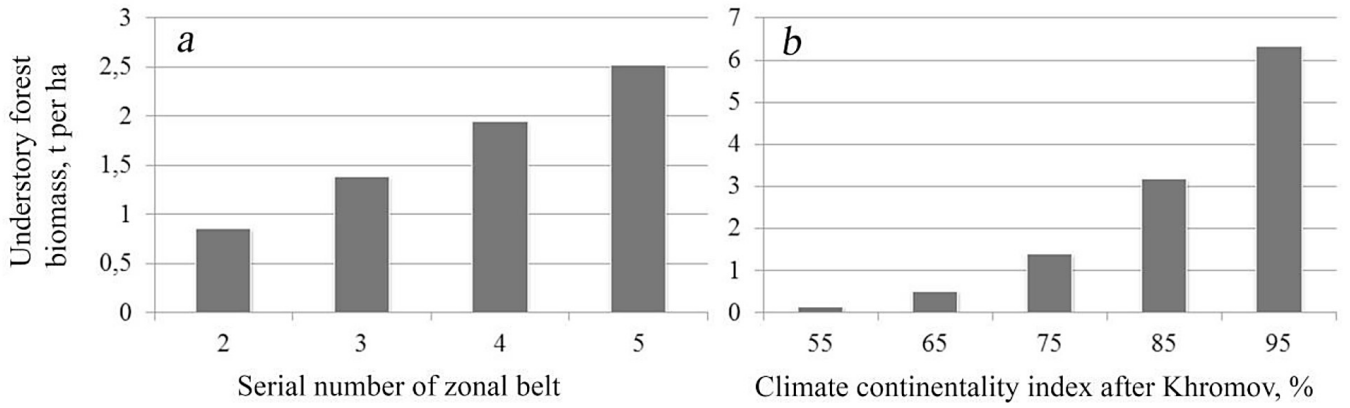

Figure 6. Dependence of calculated values of understory biomass at the stand age of 50 years upon the zonal affiliation of Populus forests in continentality index equal 75\% $(a)$ and upon continentality index after S.P. Khromov in the southern temperate zonal belt $(b)$

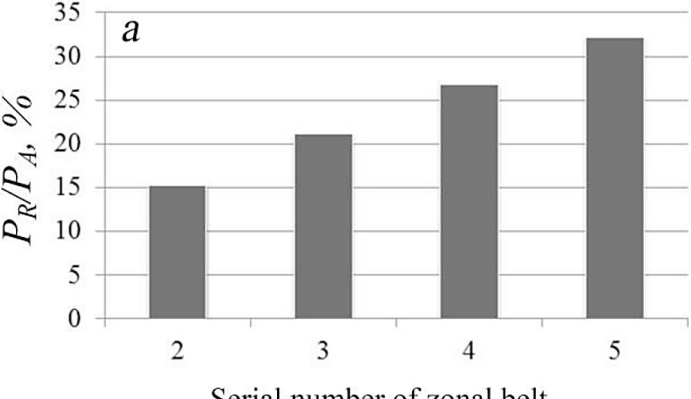

Serial number of zonal belt

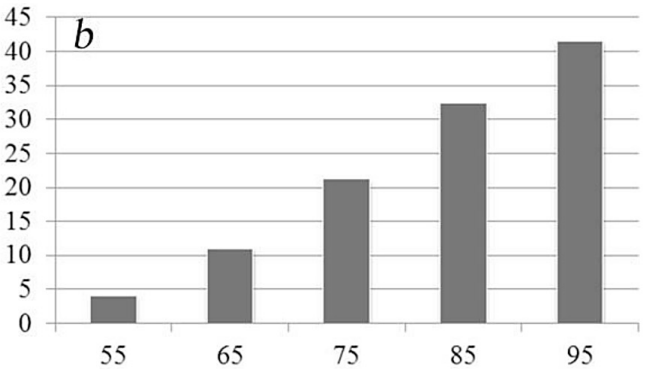

Climate continentality index after Khromov, \%

Figure 7. Dependence of $P_{R} / P_{A}$ ratio of Populus forests in the age of 50 years upon serial number of climatic zone in continentality index after S.P. Khromov equal to $75 \%(a)$ and upon climate continentality in the southern temperate zonal belt $(b)$ 


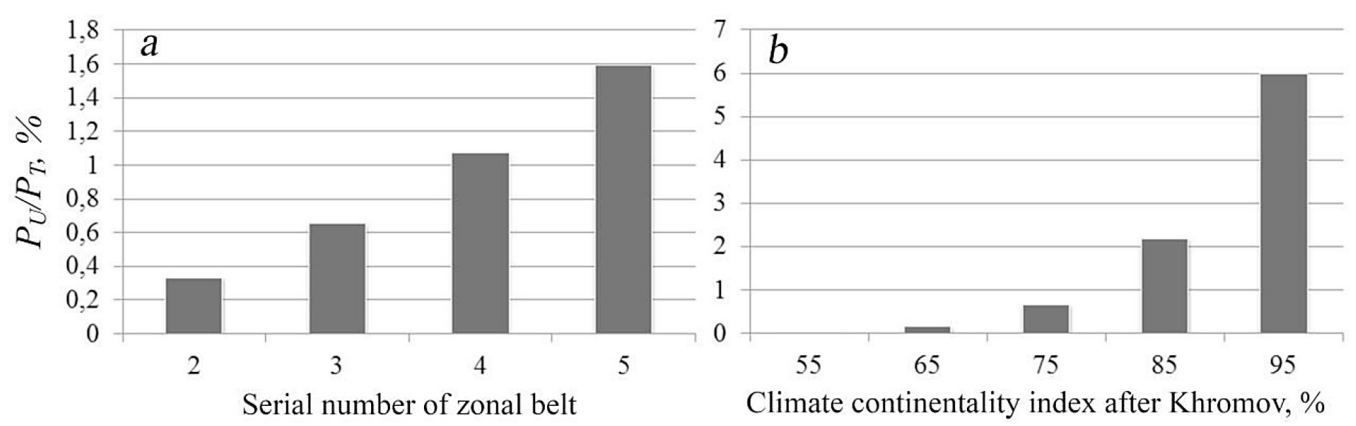

Figure 8. Dependence $P_{U} / P_{T}$ ratio of Populus forests in the age of 50 years upon serial number of climatic zone in continentality index after S.P. Khromov equal to $75 \%(a)$ and upon climate continentality in the southern temperate zonal belt $(b)$

The root: shoot ratio increases in the range between northern temperate and subequatorial zonal belts from 15 to $32 \%$ and within the southern temperate zone it monotonically increases from $5 \%$ on the oceanic coasts to $40 \%$ near continentality pole. The ratio of understory to wood story biomass increases from 0.3 to $1.6 \%$ ranging from northern temperate to subequatorial zonal belt, and within the south temperate zone it monotonically increases from zero values near Atlantic and Pacific coasts, approaching the level of $40 \%$ near the continentality pole.

The results can be useful in the management of biosphere functions of forests, what is important when implementing activities on climate stabilization, as well as in the validation of the results of the simulations for assessing the carbondepositing forest capacity.

\section{Acknowledgements}

We thank the anonymous referees for their useful suggestions.

\section{REFERENCES}

1. Alisov B.P., Poltaraus B.V. 1972. Climatology. Lomonosov Moscow State University, Moscow, pp. 300.

2. Bazilevich N.I., Rodin L.E. 1967. Schematic Maps of Productivity and Biological Turnover of Elements in the main Types of Land vegetation. Izvestiya Vsesoyuznogo Geograficheskogo Obshchestva, 99(3), 190-194.
3. Grigoriev A.A. Budyko, M.I. 1956. On the periodic law of geographical zoning. Doklady Akadimii Nauk SSSR, 110(1), 129-132.

4. Khromov, S.P.K. 1957. To a problem of climate continentality. Izvestiya Vsesoyuznogo Geograficheskogo Obshchestva, 89(3), 221-225.

5. Komarov V. L. 1921. Meridional zonality of organisms. Proceedings of the $1^{\text {st }}$ All-Russian Congress of Russian Botanists in Petrograd, No. 3. Petrograd, 27-28.

6. Lavrenko E.M., Andreev V.N., Leont'ev V.L. 1955. Productivity profile of aboveground part of natural plant cover from tundras to deserts in the USSR. Botanicheskii Zhurnal, 40(3), 415-419.

7. Lieth H. 1974. Modeling the primary productivity of the World. Ekologiya, 2, 13-23.

8. Nazimova D.I. 1995. Climatic ordination of forest ecosystems as a basis of their classification. Lesovedenie, 4, 63-73.

9. Rosenzweig M. L. 1968. Net primary productivity of terrestrial communities: Prediction from climatological data. The American Naturalist, 102(923), 67-74.

10. Tolmachev A. I. 1962. Fundamentals of habitats: an introduction to plant horology. Leningrad, State University Publishing, pp. 100.

11. Usoltsev V.A. 2013. Forest biomass and primary production database for Eurasia. CD-version. The second edition, enlarged and re-harmonized. Yekaterinburg: Ural State Forest Engineering University (http://elar.usfeu.ru/handle/123456789/3059).

12. Usoltsev V.A. 2013. Geography of biological productivity of cedar pine ecosystems in Asia. EcoPotential, 1(2) 47-67 (http://elar.usfeu.ru/handle/123456789/2802). 